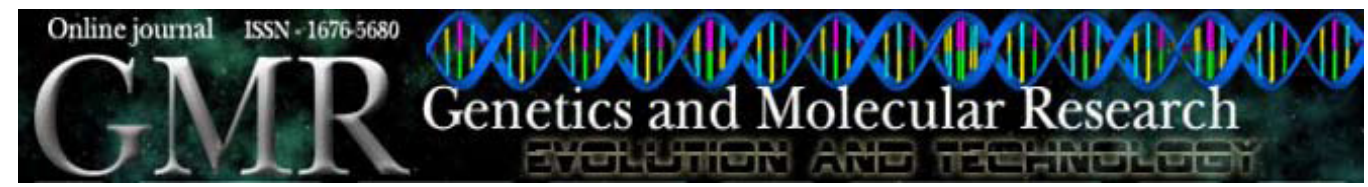

Methodology

\title{
Comparison of three methods of DNA extraction from peripheral blood mononuclear cells and lung fragments of equines
}

\author{
E.M. Santos ${ }^{1}$, J.F.R. Paula ${ }^{1}$, P.M.C. Motta ${ }^{1}$, M.B. Heinemann ${ }^{1}$, \\ R.C. Leite ${ }^{1}$, J.P.A. Haddad ${ }^{1}$, H.L. Del Puerto ${ }^{2}$ and J.K.P. Reis ${ }^{1}$ \\ 'Departamento de Medicina Veterinária Preventiva, Escola de Veterinária, \\ Universidade Federal de Minas Gerais, Belo Horizonte, MG, Brasil \\ ${ }^{2}$ Departamento de Patologia Geral, Instituto de Ciências Biológicas, \\ Universidade Federal de Minas Gerais, Belo Horizonte, MG, Brasil \\ Corresponding author: E.M. Santos \\ E-mail: elmaira27@yahoo.com.br
}

Genet. Mol. Res. 9 (3): 1591-1598 (2010)

Received March 10, 2010

Accepted May 11, 2010

Published August 17, 2010

DOI 10.4238/vol9-3gmr818

\begin{abstract}
We compared three different protocols for DNA extraction from horse peripheral blood mononuclear cells (PBMC) and lung fragments, determining average final DNA concentration, purity, percentage of PCR amplification using $\beta$-actin, and cost. Thirtyfour samples from PBMC, and 33 samples from lung fragments were submitted to DNA extraction by three different protocols. Protocol A consisted of a phenol-chloroform and isoamylic alcohol extraction, Protocol B used alkaline extraction with $\mathrm{NaOH}$, and Protocol $\mathrm{C}$ used the DNAzol ${ }^{\circledR}$ reagent kit. Protocol A was the best option for DNA extraction from lung fragments, producing high DNA concentrations, with high sensitivity in PCR amplification (100\%), followed by Protocols C and B. On the other hand, for PBMC samples, Protocol B gave the highest sensitivity in PCR amplification (100\%), followed by Protocols C and
\end{abstract}


A. We conclude that Protocol A should be used for PCR diagnosis from lung fragment samples, while Protocol B should be used for PBMC.

Key words: Protocol; DNA; Equine; PBMC; Lung

\section{INTRODUCTION}

The development of molecular biology in the last few decades has enabled the establishment of a wide variety of techniques applied to investigation in biology that have had a huge influence on medical research (Barry and Eisenstein, 1990). Today's molecular methods, such as the polymerase chain reaction (PCR) technique, have made the study of diseases and genetic disorders easier due to their capability to amplify, in an exponential way, copies of specific DNA sequences from clinical samples (Mesquita et al., 2001), and thus provide good sensitivity for infectious agent detection (Kim and Casey, 1994; Langemeier et al., 1996; Nagarajan and Simard, 2001; Cook et al., 2002; Fernandes et al., 2004).

In order to perform a PCR diagnostic test, a protocol for DNA extraction from clinical specimens that is easy to perform, fast and that generates contaminant-free product is required to prevent unspecific amplifications (Löffler et al., 1997; Veloso et al., 2000). Therefore, a technique to obtain enough quantity, purity and integrity of nucleic acids from tissues and cells is essential to molecular biology procedures (Mesquita et al., 2001; Loeffler et al., 2002; González-Mendoza et al., 2010). The selection of the best method also requires knowledge of the risks to human health, the environment and the final cost.

Usual methods for DNA extraction using organic solvents, followed by alcohol precipitation, are appropriate for cell samples. New methodologies for DNA extraction include a single step of proteinase K digestion (without the use of organic solvents), DNA adsorption in silica membrane or simple methods of sequential precipitation of proteins and DNA (Cler et al., 2006). DNA extraction using phenol, chloroform and isoamylic alcohol is the usual way to obtain DNA from clinical samples. The treatment of samples with proteinase $\mathrm{K}$ is often incorporated for protein degradation in sub-tetrameric fragments, improving PCR efficiency (Wiegers and Hilz, 1971), and also generating a higher amount of DNA in comparison to protocols that use physical methods (Yang et al., 2007).

Therefore, efficiency in the DNA extraction method using phenol, chloroform and isoamylic alcohol requires time and toxic solution manipulation, due to the organic solvents that may be hazardous to the environment and to the technician, and also several washing and centrifugation steps increasing the risk of sample contamination (Fernandes et al., 2004). Several methods have been proposed as an alternative to the use of phenol and chloroform, such as commercial kits for DNA extraction. The use of kits offers a low risk of manipulation and they are faster than conventional protocols, but the amount of DNA recovered from the commercial kits is highly variable (Loffler et al., 1997).

The objective of the present study was to compare three DNA extraction protocols from peripheral blood mononuclear cells (PBMC) and lung fragments. The following protocols for DNA extraction were tested: Protocol A used extraction with phenol-chloroform and isoamylic alcohol; Protocol B used alkaline extraction with $\mathrm{NaOH}$, and Protocol $\mathrm{C}$ used extraction using DNAzol ${ }^{\circledR}$ reagent. The results of DNA extraction from the different protocols were tested for final DNA concentration, purity, cost, and $\beta$-actin amplification. 


\section{MATERIAL AND METHODS}

\section{Blood sample collection and preparation}

Thirty-four blood samples, collected from the jugular veins of equids (Itaobim and Araguari meat-packing plants, MG, Brazil), after antisepsis using iodine in alcohol solution, were collected in 4-mL Vacuntainer ${ }^{\circledR}$ tubes containing EDTA (VACUETTE ${ }^{\circledR}$, Greiner Bio-One Brasil, Americana, SP, Brazil). Whole blood was centrifuged at $300 \mathrm{~g}$ for $10 \mathrm{~min}$ and the leukocyte layer was separated, adding the same volume of PBS $\left(0.01 \mathrm{M} \mathrm{PO}_{4}, 0.15 \mathrm{M} \mathrm{NaCl}, \mathrm{pH}\right.$ 7.2). The resulting mixture was carefully placed on Ficoll-Paque, followed by centrifugation at $700 \mathrm{~g}$ for $30 \mathrm{~min}$. The corresponding leukocyte portion was separated in another tube and centrifuged at $300 \mathrm{~g}$ for $10 \mathrm{~min}$. The supernatant was discarded and the material precipitated was washed with $1 \mathrm{~mL}$ PBS $\left(0.01 \mathrm{M} \mathrm{PO}_{4}, 0.15 \mathrm{M} \mathrm{NaCl}, \mathrm{pH} 7.2\right)$ by centrifugation at $300 \mathrm{~g}$ for $10 \mathrm{~min}$ and resuspended in $200 \mu \mathrm{L}$ NET $100(5 \mathrm{M} \mathrm{NaCl}, 1 \mathrm{M}$ Tris-HCl, $0.5 \mathrm{M}$ EDTA, pH 8.0 ) to be stored at $-20^{\circ} \mathrm{C}$. The concentration of cells was determined by manual cell counting using a Neubauer chamber and divided into three equal aliquots.

\section{Lung fragment collection and preparation}

Thirty-three equid lung fragment samples were collected and prepared as described by Santos (2006). They were collected in the Itaobim and Araguari meat-packing plants, located in $\mathrm{MG}$, Brazil, and stored at $-70^{\circ} \mathrm{C}$ until use. Two grams lung fragment was macerated in a grail with a pestle and sterile sand. To each sample, $8 \mathrm{~mL}$ Hanks' solution was added (BSS Hanks, pH 7.5, CultiLab ${ }^{\circledR}$ ). Samples were centrifuged at $900 \mathrm{~g}$ for $35 \mathrm{~min}$, the supernatant cells were collected and the concentration was determined by manual cell counting using a Neubauer chamber. Samples were divided into three equal aliquots (one aliquot for each protocol), and frozen at $-20^{\circ} \mathrm{C}$ until the moment of use.

\section{DNA extraction}

\section{Protocol A: DNA extraction using phenol-chloroform and isoamylic alcohol}

The method for DNA extraction from PBMC and from lung fragments by phenolchloroform and isoamylic alcohol (Sigma-Aldrich, SP, Brazil) consisted of the addition to each sample of $500 \mu \mathrm{L}$ STE solution (10 mL 1 M Tris-HCl, pH 8.0, 2 mL 0.5 M EDTA, pH 8.0, and $5 \mathrm{~mL} 3 \mathrm{M} \mathrm{NaCl}), 150 \mu \mathrm{L} \mathrm{20 \%}$ SDS and of $20 \mu \mathrm{L}$ proteinase $\mathrm{K}(5 \mathrm{mg} / \mathrm{mL})$, followed by incubation in a water bath at $56^{\circ} \mathrm{C}$ for $18 \mathrm{~h}$. Subsequently, a suspension of $80 \%(\mathrm{v} / \mathrm{v})$ isopropanol (Sigma-Aldrich) was added and then centrifuged at $15,000 \mathrm{~g}$ for $30 \mathrm{~min}$. The precipitated material was resuspended in ultra-pure water, and the solution washed twice in a mixture of phenol-chloroform and isoamylic alcohol (25:24:1), and the supernatant aqueous phase was recovered using a final wash using a mixture of chloroform-isoamylic alcohol (24:1). Sodium acetate $(3 \mathrm{M})$ and absolute ethanol (Merck, Darmstadt, Germany) were added to the solution, which was then incubated at $-20^{\circ} \mathrm{C}$ for $18 \mathrm{~h}$. After incubation, the solution was centrifuged for $30 \mathrm{~min}$ at $14,000 \mathrm{~g}$ and, subsequently, the precipitated DNA was washed with 75 and $100 \%$ ethanol and DNA was resuspended in $15 \mu \mathrm{L}$ ultra-pure water and stored at $-20^{\circ} \mathrm{C}$. 


\section{Protocol B: DNA extraction using $\mathrm{NaOH}$}

The DNA extraction with $\mathrm{NaOH}$ consisted of two washings of $100 \mu \mathrm{L}$ of the PBMC samples and macerated lung fragments with $400 \mu \mathrm{L}$ TNE $(0.1 \mathrm{M}$ Tris, $\mathrm{pH}$ 8.0, 0.15 $\mathrm{M} \mathrm{NaCl}, 0.005 \mathrm{M}$ EDTA) by centrifugation at $10,500 \mathrm{~g}$ for $3 \mathrm{~min}$. The supernant was separated and the precipitated material resuspended in $40 \mu \mathrm{L}$ lysis solution $(50 \mathrm{mM} \mathrm{NaOH})$. The material was homogenized using a vortex for $5 \mathrm{~min}$. The samples were heated at $95^{\circ} \mathrm{C}$ for $5 \mathrm{~min}$ in a water bath, and finally resuspended in $15 \mu \mathrm{L} 0.5 \mathrm{M}$ Tris- $\mathrm{HCl}, \mathrm{pH} 8$, and stored at $-20^{\circ} \mathrm{C}$.

\section{Protocol C: DNA extraction using DNAZOL ${ }^{\circledR}$ Genomic DNA Isolation Reagent}

The DNA extraction with DNAzol ${ }^{\circledR}$ reagent (Invitrogen, SP, Brazil) was performed according to manufacturer instructions.

\section{DNA quantification}

DNA sample concentrations were determined by spectrophotometry at the wavelength of $260 \mathrm{~nm}$ for the DNA and $280 \mathrm{~nm}$ for proteins, and the purity observed using OD 260/OD 280, in NanoDrop equipment (Thermo Fisher Scientific, Wilmington, DE, USA). Concentration results are given in $n g / \mu \mathrm{L}$, and the DNA purity results are reported as the OD 260/OD 280.

\section{$\beta$-actin PCR amplification}

To verify the quality of genomic DNA samples after the extraction procedures, a PCR for $\beta$-actin gene amplification was performed. The $\beta$-actin gene was selected because it is a constitutive gene in equids. A pair of oligonucleotide primers was established using the 3_www_results.cgi v 0.4 software, based on sequences of equine $\beta$-actin stored at the genome bank Genbank (ncbi.nlm.nih.gov). The sequences of the left and right primers are 5'-CGACATCCGTAAGGACCTGT-3' and 5'-GTGGACAATGAGGCCAGAAT-3', respectively, and a fragment of $191 \mathrm{bp}$ was amplified. PCR consisted of $10 \mathrm{mM}$ Tris-HCl, pH 9.0, $50 \mathrm{mM} \mathrm{KCl}, 1.5 \mathrm{mM} \mathrm{MgCl}, 0.1 \%$ Triton X-100, $20 \mathrm{mM}$ of each dNTP, $10 \mathrm{pM}$ of each specific primer, $1 \mathrm{U}$ Taq DNA polymerase (Invitrogen), and $1 \mu \mathrm{g}$ DNA, in a final volume of $20 \mu \mathrm{L}$. The amplification using this primer pair consisted of an initial denaturation cycle of $95^{\circ} \mathrm{C}$ for $3 \mathrm{~min}$, followed by 37 cycles of $94^{\circ} \mathrm{C}$ for $30 \mathrm{~s}, 56^{\circ} \mathrm{C}$ for $30 \mathrm{~s}$ and $72^{\circ} \mathrm{C}$ for $30 \mathrm{~s}$ and a final extension cycle of $72^{\circ} \mathrm{C}$ for $7 \mathrm{~min}$. DNA extracted from Equine Dermal cell lineage was used as a positive control and the PCR reagent as a negative control. The amplified fragment was visualized by $1 \%$ agarose gel electrophoresis, stained with ethidium bromide at a final concentration of $0.5 \mu \mathrm{g} / \mathrm{mL}$.

\section{Cost estimation}

The costs of Protocols A, B and C were calculated based on materials and reagents used for each extraction, divided by the number of samples processed. 


\section{Statistical analysis}

The analysis of variance was performed using a general linear mode by the STATA 10 software that controls two factors: three different protocols for DNA extraction and two types of samples (PBMCs and lung fragments). The interaction between the two factors was also tested. The Student $t$-test was used to compare the average values.

\section{RESULTS}

The results from DNA extractions compared by $\beta$-actin amplification in PCR, generating a fragment of $191 \mathrm{bp}$ (Figure 1), demonstrated that Protocol A extractions resulted in $100 \%$ $\beta$-actin amplification in lung fragment samples, and $94.1 \%$ in PBMC samples. Therefore, DNA extractions using Protocol B resulted in $84.8 \% \beta$-actin amplification in lung fragment samples, while in PBMC samples it resulted in amplifications of $100 \%$. On the other hand, DNA extractions using Protocol $\mathrm{C}$ resulted in $100 \% \beta$-actin amplification in lung fragment samples, the same as the result using Protocol A. But, the $\beta$-actin amplification efficiency in PBMC samples was very low, just 55.8\% (Table 1). Hence, Protocols A and C presented sensitivity of $100 \%$ for $\beta$-actin amplification in lung fragment samples. Conversely, Protocol $\mathrm{B}$ presented higher sensitivity in PCR amplification in PBMC samples when compared with Protocols A and C (Table 1).

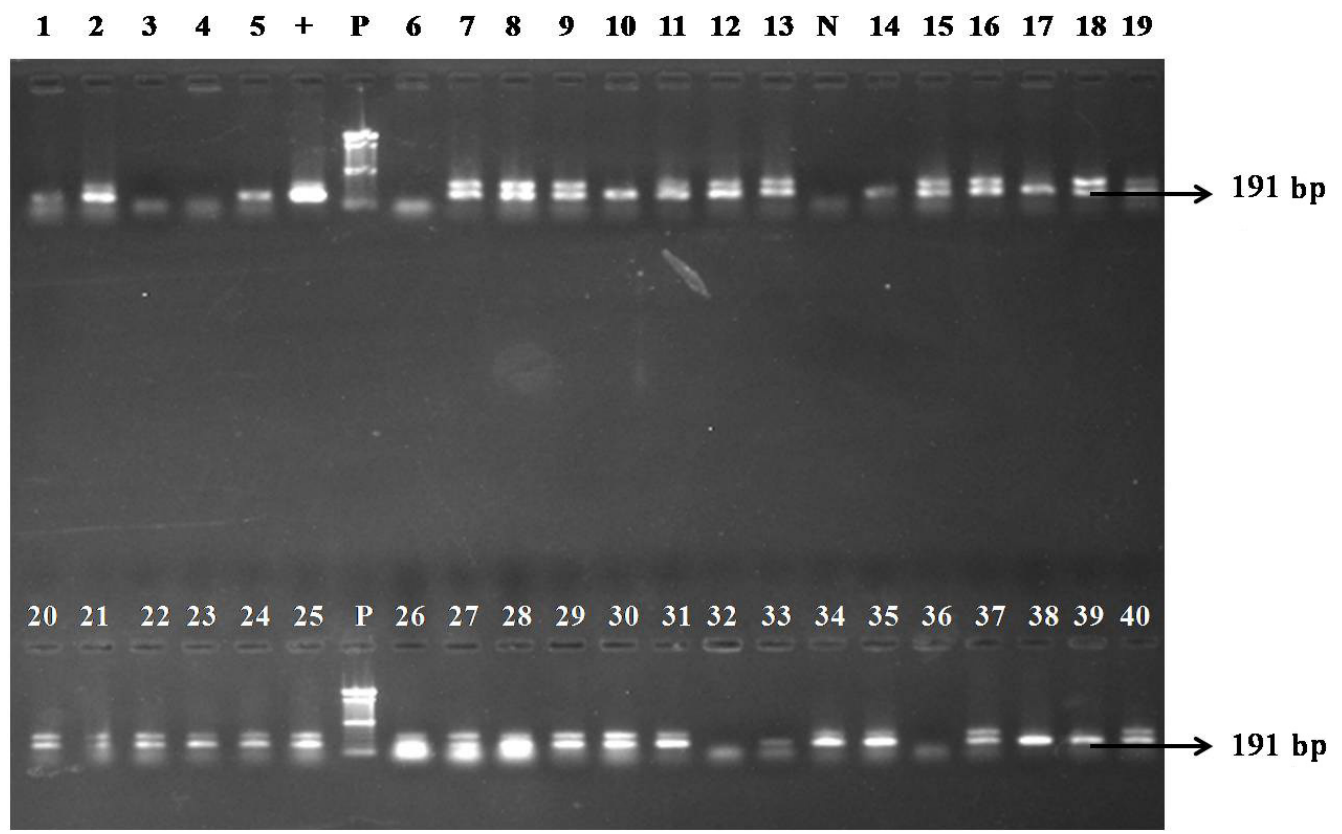

Figure 1. Agarose gel (1\%) electrophoresis, stained with ethidium bromide. PCR results from $\beta$-actin gene amplification (fragment with $191 \mathrm{bp}$ ) $++=$ Positive control; $\mathrm{P}=$ DNA ladder. Lanes $1-19=\beta$-actin amplification in PBMC samples; lanes 20-40 $=\beta$-actin amplification in lung fragment samples; $\mathrm{N}=$ negative control. 
Table 1. DNA concentration and purity (OD 260/OD 280), cost and PCR $\beta$-actin amplification percent obtained from the three DNA extraction techniques for peripheral blood mononuclear cell (PBMC) and lung fragment samples from equids.

\begin{tabular}{lcccrc}
\hline Protocols & $\begin{array}{c}\text { Average DNA } \\
\text { concentration }(\mathrm{ng} / \mu \mathrm{L})\end{array}$ & OD 260/OD 280 & Samples & $\begin{array}{c}\text { \% of } \beta \text {-actin samples } \\
\text { amplified by PCR }\end{array}$ & $\begin{array}{c}\text { Cost estimation } \\
(\mathrm{R} \$)\end{array}$ \\
\hline PA - PBMC & 419 & 2.04 & 34 & $94.1 \%$ & 1.49 \\
PB - PBMC & 1078 & 2.03 & 34 & $100.0 \%$ & 0.02 \\
PC - PBMC & 951 & 2.07 & 34 & $55.8 \%$ & 2.84 \\
PA - Lung & 2706 & 1.86 & 33 & $100.0 \%$ & 0.02 \\
PB - Lung & 802 & 1.27 & 33 & $84.8 \%$ & 2.84 \\
PC - Lung & 947 & 1.85 & $100.0 \%$ & \\
\hline
\end{tabular}

$\mathrm{PA}=$ Protocol $\mathrm{A} ; \mathrm{PB}=$ Protocol $\mathrm{B} ; \mathrm{PC}=$ Protocol $\mathrm{C}$.

In order to analyze the PCR results from $\beta$-actin amplification, the Fisher test was used. In Protocol A, PCR results did not differ among the samples evaluated $(\mathrm{P}=0.492)$; in Protocol B, results differed marginally $(\mathrm{P}=0.053)$, and in Protocol C, PCR results were significantly different $(\mathrm{P}<0.001)$, due to the high percentage of negative amplifications for DNA samples extracted from PBMCs (Table 1).

Comparing DNA sample quantification from lung fragments, we observed that the extraction with Protocol A gave the highest DNA concentration, as compared with Protocols $\mathrm{B}$ and $\mathrm{C}(\mathrm{P}<0.001)$ (Figure 2). Therefore, in PBMC samples, Protocol B obtained a higher concentration of DNA (Table 1), and Protocol A presented a lower yield of DNA than Protocols $\mathrm{B}$ and $\mathrm{C}(\mathrm{P}<0.05)$ (Figure 2).

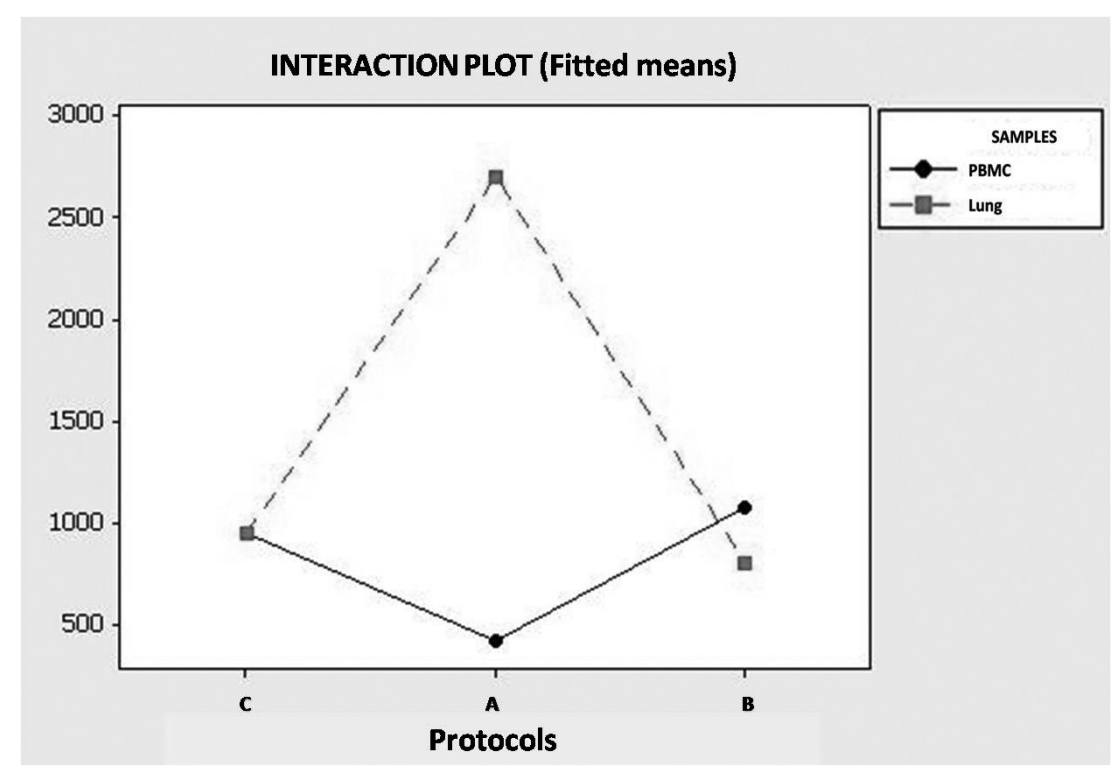

Figure 2. Variance analysis of the interaction between the protocols used and samples tested [peripheral blood mononuclear cells (PBMC) and lung fragment]. 
Evaluating protocols by the time consumed performing the extractions, Protocol C was the fastest and the most practical in execution, with fewer steps during the procedure as compared with Protocols A and B. Protocol A is the most time-consuming method, requiring 3 days to perform, and also using toxic reagent. When comparing protocols by cost, Protocol B presented the lowest costs for DNA extraction, followed by Protocol A and then Protocol C (Table 1). The higher purity for samples (OD 260/OD 280) was observed using Protocols A and $\mathrm{C}$ for PBMCs and lung fragments (Table 1).

Evaluating the two different samples (lung fragment and PBMC) using Protocol A, a statistically significant difference $(\mathrm{P}<0.001)$ was observed. However, no statistical significant difference was observed in samples extracted by Protocols B and C (Figure 2).

The existence of interactions prevents separate comparison of the different protocols and samples. So, DNA concentration results for Protocols B and C were similar, regardless the kind of sample used. On the other hand, Protocol A was more efficient in extracting DNA from lung fragments than in PBMC samples.

\section{DISCUSSION}

In the present study, the DNA concentrations by the different protocols are in agreement with the $\beta$-actin gene amplification using PCR, which revealed a higher amplification of the gene in lung fragment samples using Protocol A, and in PBMC samples using Protocol B. Upon comparison of the three methods used for quantifying DNA and the percentage of PCR amplifications, we conclude that Protocol A is the most suitable for DNA extraction in lung fragments. Although it is hard to perform, Protocol A produces high DNA concentrations, with $100 \%$ of $\beta$-actin gene amplification, avoiding false negatives in diagnostic use. The same results were observed in DNA from lung fragments extracted using Protocol C, a fast protocol, with few steps involving sample manipulation, but it is an expensive method for use in routine extractions. According to PCR results, Protocol B was not efficient in comparison with Protocols $\mathrm{A}$ and $\mathrm{C}$ in lung fragments, which can be explained by the various shaking steps that may have contributed to damaging the structure of the nucleic acid in some samples.

Therefore, for PBMC samples, Protocol B was the only one that produced $100 \%$ $\beta$-actin gene amplifications. Protocol A produced higher DNA concentrations, though Protocol $\mathrm{B}$ was more viable, since the final product is more accessible to PCR, and is also not harmful to the health of technicians, whereas Protocol A takes three days and uses toxic chemicals (Fernandes et al., 2004). Besides, Protocol B presented the lowest cost for DNA extraction in comparison with the other methods.

Several methods have been suggested to remove the risks posed by phenol to technicians and the environment. The use of manufactured kits decreases the risks and the time needed for DNA extraction, but the quality and quantity of DNA recovered vary widely (Loffler et al., 1997).

Finally, Protocol C did not show great efficiency for DNA extraction from PBMC samples, demonstrated by $44.2 \%$ of negative $\beta$-actin amplification in samples tested by PCR, but this method provided great results in DNA extraction from lung fragments (Table 1). With few sample manipulation steps, it can be recommended for DNA extraction from lung fragments.

So, Protocol $\mathrm{C}$ is the most highly recommended for DNA extraction from lung fragments, because of its advantages, such as the short time required for the procedure, high DNA concentrations, and high sensitivity in PCR amplifications. Therefore, Protocol B is the most 
highly recommended for DNA extraction from PBMC, with high sensitivity in PCR amplifications, low cost and easy execution.

\section{ACKNOWLEDGMENTS}

We would like to thank Conselho Nacional de Desenvolvimento Científico e Tecnológico - "National Council of Technological and Scientific Development" - CNPq, Fundação de Amparo à Pesquisa do Estado de Minas Gerais - FAPEMIG, and CAPES for financial support.

\section{REFERENCES}

Barry I and Eisenstein MD (1990). The polymerase chain reaction. N. Engl. J. Med. 322: 178-183.

Cler L, Bu D, Lewis C and Euhus D (2006). A comparison of five methods for extracting DNA from paucicellular clinical samples. Mol. Cell Probes 20: 191-196.

Cook RF, Cook SJ, Li FL, Montelaro RC, et al. (2002). Development of a multiplex real-time reverse transcriptasepolymerase chain reaction for equine infectious anemia virus (EIAV). J. Virol. Methods 105: 171-179.

Fernandes JV, Meissner RV, Fernandes TAAM, Rocha LRM, et al. (2004). Comparação de três protocolos de extração de DNA a partir de tecido fixado em formol e incluído em parafina. J. Bras. Patol. Med. Lab. 40: 141-146.

González-Mendoza D, Argumedo-Delira R, Morales-Trejo A, Pulido-Herrera A, et al. (2010). A rapid method for isolation of total DNA from pathogenic filamentous plant fungi. Genet. Mol. Res. 9: 162-166.

Kim CH and Casey JW (1994). In vivo replicative status and envelope heterogeneity of equine infectious anemia virus in an inapparent carrier. J. Virol. 68: 2777-2780.

Langemeier JL, Cook SJ, Cook RF, Rushlow KE, et al. (1996). Detection of equine infectious anemia viral RNA in plasma samples from recently infected and long-term inapparent carrier animals by PCR. J. Clin. Microbiol. 34: 1481-1487.

Loeffler J, Schmidt K, Hebart H, Schumacher U, et al. (2002). Automated extraction of genomic DNA from medically important yeast species and filamentous fungi by using the MagNA Pure LC system. J. Clin. Microbiol. 40: 2240-2243.

Löffler J, Hebart H, Schumacher U, Reitze H, et al. (1997). Comparison of different methods for extraction of DNA of fungal pathogens from cultures and blood. J. Clin. Microbiol. 35: 3311-3312.

Mesquita RA, Anzai EK, Oliveira RN and Nunes FD (2001). Evaluation of 3 methods of DNA extraction from paraffinembedded material for the amplification of genomic DNA using PCR. Pesqui. Odontol. Bras. 15: 314-319.

Nagarajan MM and Simard C (2001). Detection of horses infected naturally with equine infectious anemia virus by nested polymerase chain reaction. J. Virol. Methods 94: 97-109.

Santos EM (2006). Avaliação da Reação em Cadeia da Polimerase (PCR) em PBMC e Lavado Broncoalveolar para o Diagnóstico da Anemia Infecciosa Eqüina. Escola de Veterinária, Universidade Federal de Minas Gerais, Belo Horizonte.

Veloso IF, Lopes MT, Salas CE and Moreira EC (2000). A comparison of three DNA extractive procedures with Leptospira for polymerase chain reaction analysis. Mem. Inst. Oswaldo Cruz 95: 339-343.

Wiegers U and Hilz H (1971). A new method using 'proteinase K' to prevent mRNA degradation during isolation from HeLa cells. Biochem. Biophys. Res. Commun. 44: 513-519.

Yang Z, Xiao Y, Zeng GM, Xu Z, et al. (2007). Comparison of methods for total community DNA extraction and purification from compost. Appl. Microbiol. Biotechnol. 74: 918-925. 